\title{
Combined and Individual Pre-sowing Seed Treatments of Electric, Magnetic and Botanicals on Growth, Yield and Yield Attributing Traits of Tomato [Lycopersicum esculentum (L.)]
}

\author{
Marneni Jaya Surekha* and Prashant Kumar Rai
}

Department of Genetics and Plant Breeding, Naini Agricultural Institute, Sam Higginbottom University of Agriculture, Technology and Sciences, Prayag Raj, 211007 U. P., India

*Corresponding author

\section{Keywords}

Magnetic field, Electric field, Neem leaf extract, Panchagavya, growth, yield and tomato

Article Info

Accepted: 18 March 2021 Available Online: 10 April 2021

\section{A B S T R A C T}

The experiment was conducted in field and laboratory at Department of Genetics and Plant Breeding, Naini Agricultural Institute, SHUATS, U.P. during rabi season 2020, in order to standardize the best method of priming specific to tomato (var - Pusa Ruby). Tomato seeds are treated with same intensities of Magnetic field $100 \mathrm{~mA}$ for different durations i.e (1min, $5 \mathrm{~min}$ and 10minutes), different intensities of electric field $(100 \mathrm{~mA}, 125 \mathrm{~mA}, 150 \mathrm{~mA}$ for $1 \mathrm{~min})$ and the combination of Magnetic(100 $\mathrm{mT})+\operatorname{electric}(100 \mathrm{~mA}$ for $2 \mathrm{~min})$, Magnetic $(100 \mathrm{mT})+\operatorname{electric}(125 \mathrm{~mA}$ for $2 \mathrm{~min})$, Neem leaf extract (3\% for $7 \mathrm{hr}$ ), Cow urine ( $25 \%$ for $7 \mathrm{hr}$ ), Panchagavya (3\% for $7 \mathrm{hr}$ and $5 \%$ for $7 \mathrm{hr}$ ). It was found that all the treatments showed a significant difference with the control. In the present investigation $\mathrm{T}_{4}-$ Electric field treatment $(100 \mathrm{~mA})$ exposure of 1 minute performed best results in field parameters like plant height $(\mathrm{cm})$ 90 DAT, days to first flower initiation, number of flowers per cluster, days to first fruits set, number of fruits per cluster, number of fruits per plant, days to maturity, fruit weight $(\mathrm{g})$, fruit yield per plant $(\mathrm{kg})$, number of seeds per fruit, 1000 seed weight and in lab parameters like germination percentage, shoot length, root length, seedling length, fresh weight, dry weight, seed vigour index - I and seed vigour index - II followed by $\mathrm{T}_{6}-$ Electric field treatment $(150 \mathrm{~mA})$ for 1 minute and $\mathrm{T}_{9}-$ neem leaf extract (3\%) for 7 hours.Hence seed treatment of tomato seeds with electric field is the best treatment when compared to magnetic field and other pre-sowing seed treatments.

\section{Introduction}

Tomato (Lycopersicum Esculentum L.) $(2 n=24)$ is an important vegetable crop and has a significant role in human nutrition and human diet. (Bhowmik et al., 2012) and it belongs to the solanaceae family, its origin is the andrean zone particularly Peru-EcuadorBolivia areas but cultivated tomato is originated in mexico. The Spanish introduced the tomato into Europe in the early $16^{\text {th }}$ century hence tomatoes have been cultivated 
and consumed in southern Europe, they became widespread in north-western Europe by the end of the $18^{\text {th }}$ Century (Harvey and Beynon., 2002). In the $17^{\text {th }}$ century, Europeans took the tomato to china, south and southeast Asia and in the $18^{\text {th }}$ century to japan and the USA (Siemonsma and Piluek., 1993).

It is the most important and remunerative vegetable crop in India. Orissa, Karnataka, Bihar, Andhra Pradesh, Madhya Pradesh, Gujarat, Maharashtra, West Bengal, Himachal Pradesh, Chhattisgarh are major tomato growing states in India. Tomato growing belts in UttarPradesh are Etawah, Mainpuri, Agra, Kanpur, Nagar, Jalaun, Meerut, Aligarh, Unnao, Barabanki, Faizabad, Firozabad, Lucknow, Sultanpur, Ghaziabad, Kanshi, RamNagar, Kanpur, Dehat, Kannauj.It is warm season vegetable, is grown extensively in cool season also. The optimum temperature required for its cultivation is $15^{\circ} \mathrm{C}$ to $27^{\circ} \mathrm{C}$. Tomatoes are grown in varied types of soilssandy loam to clay, black soil and red soilhaving proper drainage. The $\mathrm{pH}$ of the soil should be 7-8.5. Tomatoes can tolerate moderate acidic and saline soils. In red and black soils of Karnataka, Maharashtra and Madhya Pradesh, tomato hybrids are cultivated commercially. The plant usually grows up to 1 to 3 meters and above if ground is supported and tomato fruit is called a berry.

In India total tomato production is 18243 tonnes in the year 2018-19. Among which Madhya Pradesh holds the highest percentage of share $13.79 \%$ i.e., 2516 tonnes followed by Andhra Pradesh $13.72 \%$ i.e. 2503 and Karnataka $8.77 \%$ i.e. 1600 tonnes. Total area sown during 2019-2020 under tomato cultivation is 7.87 lakh ha in the country against 7.58 lakh ha of last year 2018-2019 (Agriculture cooperation and farmers welfare, April 2020). Experimental study of the effect of electricity on plant growth began in 1746 . Louis Pasteur discovered that magnetism affects plant growth when he was experimenting on the fundamentals of fermentation. He found out that the earth's magnetism affects the growth of plants. This concept can be effectively utilized in agricultural areas. The application of electricity, magnetism, monochrome light and sound can stimulate the growth of plants to a great extent. The energies are applied to the seeds, plants, soil or the water and nutrients. (Rio and Rio et al., 2013)

Nowadays, electric and magnetic fields are used as a non-chemical method in agriculture (Das and Bhattacharya, 2006). Lately, the use of physical methods for plant growth simulations is getting more general due to the less damaging effects on the environment (Aladjaadjiyan, 2010). Electric field treatment causes changes in various parameters like water absorbing capacity of seeds (Mahajan and Pandey 2014).Both magnetic and electric fields significantly affect seed germination. Electrically treated seeds result in better seedling growth, stem height and root length compared with non-exposed seeds (Kiatgamjorn et al., 2002). Possible approaches include the treatment with electromagnetic waves (EWs), magnetic -field (MFs), ultrasounds (US), and ionizing radiations (IR). Food treatment with IR, which enhances its microbiological safety and storability, has been one of the most studied technologies of the $20^{\text {th }}$ century (Farkas and Mohacsi-Farkas, 2011).

\section{Materials and Methods}

The variety of tomazo (var. PUSA rub) were stored for one planting season. After storage, seeds were primed with different doses of Distill water, Polyethylene Glycol, Sodium Chloride, Magnetic and Electric doses. The treatments used at different concentrations for priming were $\mathrm{T}_{0}$-Control, $\mathrm{T}_{1}$-Magnetic field (100 $\mathrm{mT}$ for $1 \mathrm{~min}$ ), $\mathrm{T}_{2}$-Magnetic field (100 
$\mathrm{mT}$ for $5 \mathrm{~min}$ ), $\mathrm{T}_{3}$-Magnetic field (100 $\mathrm{mT}$ for $10 \mathrm{~min}$ ), $\mathrm{T}_{4}$-Electric field (100 $\mathrm{mA}$ for $1 \mathrm{~min}$ ), $\mathrm{T}_{5}$-Electric field(125 $\mathrm{mA}$ for $\left.1 \mathrm{~min}\right), \mathrm{T}_{6^{-}}$ Electric field(150 $\mathrm{mA}$ for $1 \mathrm{~min}), \mathrm{T}_{7^{-}}$ Magnetic(100 mT)+electric (100 mA for 2 min), $\mathrm{T}_{8}$-Magnetic $(100 \mathrm{mT})+$ electric $(125 \mathrm{~mA}$ for $2 \mathrm{~min}$ ), $\mathrm{T}_{9}$-Neem leaf extract ( $3 \%$ for $7 \mathrm{hr}$ ), $\mathrm{T}_{10}$-Cow urine $(25 \%$ for $7 \mathrm{hr}), \mathrm{T}_{11^{-}}$ Panchagavya $(3 \%$ for $7 \mathrm{hr})$ and $\mathrm{T}_{12^{-}}$ Panchagavya (5\% for $7 \mathrm{hr}$ ). Treated seeds of tomato were soaked in Randomized Block Design (RBD) in 03 replications for seasons [Rabi] at Field Experimentation Centre, Department of Genetics and Plant Breeding and seed quality experiment were conducted in Post Graduate Laboratory, Department of Genetics and Plant Breeding and Laboratory of Physics, Department of Physics, Sam Higginbottom University of Agriculture, Technology \& Sciences, Allahabad (U.P.)

\section{Analysis of variance}

The analysis of variance for different characters is presented in (Table 1-2). Mean performance of 12 characters viz., plant height 90 DAT $(\mathrm{cm})$, days to first flower initiation, number of flowers per cluster, days to first fruit set, number of fruits set per cluster, number of fruits per plant, days to maturity, fruit weight $(\mathrm{g})$, fruit yield per plant $(\mathrm{kg})$, number seeds per fruit, 1000 seed weight $(\mathrm{g})$ were subjected to analysis of variance for experimental design. Analysis of variance was carried out for 12 characters to partition the total variation in 2020. The mean sum of squares due to treatments showed significance for all characters under study at 5\% level of significance. Thus, indicate selection for different quantitative characteristics for tomato improvement.

\section{Mean performance}

Significant differences were observed on all the growth, field emergence yield and yield components tomazo (var. PUSA rub) due to treatments. Perusal from table that significantly maximum increase in plant height ranged from 93.52 to 135.75 with the mean value of 109.63 Maximum plant height (135.75) was recorded by $\mathrm{T}_{4}$ by treating the seeds with Electric field (100 mA).

In case of days to first flower initiation minimum days was recorded in $\mathrm{T}_{4}$ Electric field (100 mA) (24.06), while number of flowers per cluster was recorded in $T_{6^{-}}$ Electric field (150 mA) (6.48). Perusal from table that significantly minimum in days to first fruiting occurs by $\mathrm{T}_{4}$ - Electric field (100 $\mathrm{mA}$ ) (38.5), while highest number of fruits set per cluster was recorded in $\mathrm{T}_{4}$ - Electric field (100 mA) (5.24), also number of fruits per plant was recorded in $\mathrm{T}_{4}$ - Electric field (100 $\mathrm{mA}$ ) (49.52), however the minimum days to maturity was recorded in $\mathrm{T}_{4}$ - Electric field (100 mA) (60.38), fruit weight (g) was recorded in $\mathrm{T}_{4^{-}}$Electric field $(100 \mathrm{~mA})$ (63.78). Similarly the maximum fruit yield per plant was recorded (3.78), number of seeds per fruit was recorded (84.13), and 1000 seed weight was recorded (4.56) in $\mathrm{T}_{4^{-}}$Electric field $(100 \mathrm{~mA})$.

\section{Results and Discussion}

Tomato is an important and remunerative vegetable crop and has a significant role in human nutrition and human diet. High germination percentage and vigour of the seed are important for uniform field emergence, better crop stand and higher yield under all environmental conditions. Seed quality enhancement technology such as Priming, Pelleting, Coating, Pesticide treatments and electromagnetic treatments are widely applied to enhance the planting value of the seed. Electromagnetic stimulation for seed enhancement is non-invasive and non-aqueous technique that is more advantageous over traditional chemical processes due to the absence of toxic residues and avoidance of hydration. 
The beneficial effect of electromagnetic treatment on fresh seeds has been studied in various crops but its potential in improving vigour in comparison with other treatments has not been explored. An experiment was undertaken to evaluate the field and seed quality performance of different electromagnetic and botanical treatments in Rabi season

One of the primary objectives of seed enhancement treatments is to increase germination, total field emergence and crop stand over a wide range of environments. Electric seed treatments improve seedling emergence, root length, shoot length and seedling vigour as compared to control under lab conditions.

Electric field treatment gave better results when compared with non electric field treatment in bean sprout. Bean sprout has been chosen because its growing rate is very fast and simple to implement. Nitta et al., (2002) also Elsevier et al., (2008) reported the effect of electric field on the growth of soya seedlings. A.C electric field of 3600 and 1800 $\mathrm{V} / \mathrm{m}$ increase the average length of seedlings by about $12 \%$ and $8 \%$ respectively. And the result suggests the possibility to influence plant growth by using very low- frequency electric fields.

Rezaei-zarchi et al., (2012) examine the impact of electric and magnetic fields on the growth of alfalfa seeds. In this experiment, were tested four voltage $\mathrm{V} 1=1, \mathrm{~V} 2=3, \mathrm{~V} 3=5$ and $\mathrm{V} 4=7$ as a major factor in both $\mathrm{h} 1=2.5$ and $\mathrm{h} 2=5$ control samples.

Table.1 Analysis of variance for the 11 field parameters of Tomato

\begin{tabular}{|c|c|c|c|c|}
\hline \multirow[t]{2}{*}{ S.No. } & \multirow[t]{2}{*}{ Characters } & \multicolumn{3}{|c|}{ Mean sum of squares } \\
\hline & & $\begin{array}{l}\text { Replications } \\
\quad(d \mathbf{f}=2)\end{array}$ & $\begin{array}{l}\text { Treatments } \\
\text { (d.f.=12) }\end{array}$ & $\begin{array}{c}\text { Error } \\
(\text { d.f.=24) }\end{array}$ \\
\hline 1 & Plant height 90 DAT $(\mathrm{cm})$ & 2.65 & $185.33^{*}$ & 64.67 \\
\hline 2 & Days to 1 st flower Initiation & 0.06 & $10.69^{* *}$ & 0.46 \\
\hline 3 & Number of flowers per cluster & 1.44 & $7.22 * * *$ & 1.8 \\
\hline 4 & Days to first fruit set & 0.01 & $27.91 *$ & 0.23 \\
\hline 5 & Number of fruits set per cluster & 1.84 & 0.88 & 0.49 \\
\hline 6 & Number of fruits per plant & 1.94 & $150.41 * *$ & 27.04 \\
\hline 7 & Days to maturity & 0.68 & $63.09 *$ & 15.30 \\
\hline 8 & Fruit weight (g) & 2.03 & $136.86^{*}$ & 29.62 \\
\hline 9 & Fruit yield per plant (kg) & 0.11 & $2.23^{*}$ & 0.19 \\
\hline 10 & Number of seeds per fruit & 0.86 & $5.64^{*}$ & 0.46 \\
\hline 11 & 1000 Seed weight (g) & 1.69 & $14.95^{*}$ & 1.60 \\
\hline
\end{tabular}


Table.2 Mean performance of tomato for 11 field parameters

\begin{tabular}{|c|c|c|c|c|c|c|c|c|c|c|c|c|}
\hline \multicolumn{2}{|c|}{ Treatments } & $\begin{array}{c}\text { Plant } \\
\text { height } 90 \\
\text { DAT }(\mathrm{cm})\end{array}$ & $\begin{array}{c}\text { Days to } \\
\text { first } \\
\text { flower } \\
\text { initiation }\end{array}$ & $\begin{array}{c}\text { Number } \\
\text { of } \\
\text { flowers } \\
\text { per } \\
\text { cluster }\end{array}$ & $\begin{array}{c}\text { Days } \\
\text { to } \\
\text { first } \\
\text { fruit } \\
\text { set }\end{array}$ & $\begin{array}{c}\text { Number } \\
\text { of fruit } \\
\text { set per } \\
\text { cluster }\end{array}$ & $\begin{array}{c}\text { Number } \\
\text { of fruits } \\
\text { per } \\
\text { plant }\end{array}$ & $\begin{array}{l}\text { Days to } \\
\text { maturity }\end{array}$ & $\begin{array}{c}\text { Fruit } \\
\text { weight(g) }\end{array}$ & $\begin{array}{l}\text { Fruit } \\
\text { yield } \\
\text { per } \\
\text { plant } \\
\text { (kg) }\end{array}$ & $\begin{array}{c}\text { Number } \\
\text { of seeds } \\
\text { per } \\
\text { fruit }\end{array}$ & $\begin{array}{c}1000 \\
\text { Seed } \\
\text { weight } \\
\text { (g) }\end{array}$ \\
\hline \multicolumn{2}{|c|}{ Control } & 93.52 & 24.06 & 4.15 & 38.06 & 3.16 & 30.62 & 76.96 & 41.22 & 1.27 & 55.26 & 3.40 \\
\hline \multicolumn{2}{|c|}{$\mathrm{T}_{1}$} & 99.75 & 26.5 & 4.73 & 38.5 & 3.73 & 39.66 & 69.25 & 54.38 & 2.56 & 66.46 & 3.73 \\
\hline \multicolumn{2}{|c|}{$\mathrm{T}_{2}$} & 102.5 & 24.29 & 5.39 & 40.36 & 3.75 & 35.33 & 68.8 & 48.62 & 3.45 & 70.64 & 3.53 \\
\hline \multicolumn{2}{|c|}{$\mathrm{T}_{4}$} & 135.75 & 33.02 & 6.33 & 48.62 & 5.24 & 49.52 & 63.33 & 63.78 & 2.67 & 84.13 & 4.56 \\
\hline \multicolumn{2}{|c|}{$\mathrm{T}_{5}$} & 105.25 & 27.54 & 4.45 & 39.51 & 4.79 & 42.62 & 67.75 & 52.04 & 3.21 & 58.2 & 3.51 \\
\hline \multicolumn{2}{|c|}{$\mathrm{T}_{6}$} & 124.25 & 38.62 & 6.48 & 52.43 & 5.01 & 48.28 & 65.28 & 61.57 & 1.69 & 82.53 & 4.18 \\
\hline \multicolumn{2}{|c|}{$\mathrm{T}_{7}$} & 112.35 & 28.26 & 4.22 & 48.47 & 3.83 & 40.13 & 66.31 & 47.3 & 3.26 & 69 & 3.62 \\
\hline \multicolumn{2}{|c|}{$\mathrm{T}_{8}$} & 102.46 & 24.29 & 4.57 & 39.89 & 3.46 & 39.33 & 62.65 & 55.42 & 3.78 & 75.54 & 3.57 \\
\hline \multicolumn{2}{|c|}{$\mathrm{T}_{9}$} & 123.46 & 28.31 & 6.02 & 38.72 & 4.38 & 43.24 & 71.36 & 58.69 & 3.55 & 81.53 & 4.04 \\
\hline \multicolumn{2}{|c|}{ G-Mean } & 109.63 & 28.24 & 5.21 & 42.45 & 4.13 & 40.55 & 66.70 & 52.08 & 2.83 & 70.98 & 3.77 \\
\hline \multicolumn{2}{|c|}{ F- test } & $\mathrm{S}$ & $\mathrm{S}$ & $\mathrm{S}$ & $\mathrm{S}$ & $\mathrm{S}$ & $\mathrm{S}$ & $\mathrm{S}$ & $\mathrm{S}$ & $\mathrm{S}$ & $\mathrm{S}$ & $\mathrm{S}$ \\
\hline \multirow[t]{2}{*}{ Range } & Min & 135.75 & 38.62 & 6.48 & 52.43 & 5.24 & 49.52 & 76.96 & 63.78 & 3.78 & 84.13 & 4.56 \\
\hline & $\max$ & 93.52 & 24.06 & 4.15 & 38.06 & 3.16 & 30.62 & 60.38 & 41.22 & 1.63 & 55.26 & 3.4 \\
\hline \multicolumn{2}{|c|}{ S.Ed(m) } & 4.021 & 1.34 & 0.54 & 7.11 & 0.41 & 2.6 & 1.96 & 3.79 & 0.21 & 0.91 & 0.11 \\
\hline \multicolumn{2}{|c|}{ C.D. at $5 \%$} & 7.15 & 4.4 & 1.54 & 4.69 & 2.24 & 7.6 & 5.83 & 9.66 & 1.64 & 2.6 & 0.32 \\
\hline
\end{tabular}


The results showed that the maximum germination is owned by treatment of V4h1 and $\mathrm{V} 3 \mathrm{~h} 2$. The highest and lowest root is in V4h1 and control groups, respectively. The electric field effectively impacted on root length and the most effective treatment was V4h1. The highest fresh weight of plant obtained in at V7 and 2/5 hours. The results of this paper showed the electric field has had a significant impact of growth characteristics and seed alfalfa. And with the treatments can be achieved to the Seeds suited to the climate zone.

Also, other authors found to increase the germination percentage of seeds [ Molamofrada et al., (2013)] studied the positive effects of high voltage of electric fields on yield and germination power of seed. Electric fields with physiologic changes in seed that result in faster water absorption and respiration as well as intensifying photosynthesis of germination result in increasing the biological capacities of seed.

The results are consistent with the results of Biswas et al., (2016) where the authors reported that better germination percentage appeared when exposing the seeds of Phaseolus mungo to electric field treatment. The effects of pre-sowing electric field treatment were studied in Phaseolus mungo on water absorbing capacity of seeds, percentage of germination, a-amylase activity and gibberellic acid content of germinating seeds, and chlorophyll content and superoxide dismutase activity of leaves. Considerable enhancement was observed in all the parameters studied with increase in electric field dose. Cellular receptors of plants respond to voltage of certain magnitude and cause physiological and biochemical changes. Use of electric field in pre-sowing seed treatment for crop improvement is a novel idea for positive modulation of plant potential and consequent enhancement of productivity as very little information is available in this regard. The present investigation deals with the effect of electric field on seed germination, growth and biochemical changes of P. mungo aiming at possible augmentation of its productivity in future.

\section{References}

Aladjadjiyan A. (2010) Study of the influence of magnetic field on some biological characteristics of Zeamais. J. Central Eur. Agric., 3(2), 89-94.

Bhowmik, Debjit., Sampath Kumar,K. P., Shravan Paswan and Shwetha Srivatsav (2012) Tomato- A natural medicine and health benefits. Journal of Pharmacognosy and Phytochemistry. Vol 1(1) 33-43.

Das R and Bhattacharya R. (2006) Impact of electromagnetic field on seed germination. Indian committee for international union of radio science (URSI).

Farkas, J and Mohácsi-Farkas, C (2011) History and future of food irradiation.Trends in food science and Technology. 22(2-3):121-126.

Harvey, M. Quilley S., and Beynon, H. (2002) Exploring the Tomato: Transformations of magnetic field on seed germination of Triticum aestivum, World Journal of Agricultural. Sciences, 5:168-171.

Kiatgamjorn.P, W. Khan-ngern and S. Nitta (2002) The Effect of Electric Field on Bean Sprout Growing, International Conference on Electromagnetic Compatibility, pp. 237-241.

Mahajan and Pandey O, P. (2014) Effect of Electric and Magnetic Treatments on Germination of Bitter Gourd (Momordica Charantia) Seed, International Journal of Agriculture \& Biology, 17:351-356.

Rezaei-Zarchi, Imani, and Alikhani-Mehrjerdi, 
(2012) The Effect of Electric Field on the Germination and Growth of Medicago sativa Planet, as a native Iranian alfalfa seed, Acta Agriculturae Serbica, 17:105-115.

Rio and Rio (2013) Effect of electro-magnetic field on the growth characteristics of okra (Abelmoschus esculentus), tomato
(Solanum lycopersicum) and eggplant (Solanum melongena), International Journal of Scientific and Research Publications, Volume

Siemonsma J. S. and Piluek. K. (1993) Plant resources of south-east asia, no.8. Vegetable pudoc, Wageningen, pp 121134.

\section{How to cite this article:}

Marneni Jaya Surekha and Prashant Kumar Rai. 2021. Combined and Individual Pre-sowing Seed Treatments of Electric, Magnetic and Botanicals on Growth, Yield and Yield Attributing Traits of Tomato [Lycopersicum esculentum (L.)]. Int.J.Curr.Microbiol.App.Sci. 10(04): 568574. doi: https://doi.org/10.20546/ijcmas.2021.1004.056 